\title{
A review of the Cinericiiformes section of the genus Audre Hemming and the description of a new subspecies (Riodinidae)
}

\author{
Curtis J. Callaghan ${ }^{1}$ \\ Alexandre Soares ${ }^{2}$
}

\begin{abstract}
The systematics of the species included by STICHEL (1910) in his Cinericiiformes section of the genus Audre Hemming, 1934 are reviewed. "Audre" guttata jaibensis, ssp.n., is described from northern Minas Gerais. The synonomizing of two taxa described by Schweitzer \& Kaye, Hamearis precaria Schweitzer \& Kaye, 1941, and H. precaria ab. similis Schweitzer \& Kaye, 1941, with "Audre" cinericia is explained. Descriptions of the habitat and adult behavior of "Audre" guttata jaibensis are provided.

KEY WORDS. Riodinidae, Hamearis, Neotropical, Argentina, Uruguay, Brazil, taxonomy.
\end{abstract}

From September 1996 to July 1997, one of us (AS) and other staff of the Museu Nacional, Rio de Janeiro were invited to conduct a survey of diurnal Lepidoptera at an irrigation project in northern Minas Gerais near the Bahia border. The area sampled was east of the Rio São Francisco near the towns of Mocambinho and Jaíba ( $15^{\circ} 05^{\prime} \mathrm{S}$ and $\left.44^{\circ} 00^{\prime} \mathrm{W}\right)$. While the faunal diversity in the area was not great, with 180 species of diurnal Lepidoptera being recorded (SOARES et al. 1998), the uniqueness of the specimens captured was impressive, especially among the Riodinidae.

Of particular interest was a series of a small riodinid, which upon investigation turned out to be a new subspecies of Audre guttata (Stichel, 1910), a taxon previously known only from Argentina! Consistent morphological differences with A. guttata from Argentina suggested that the Minas population was indeed a valid geographical subspecies. A subsequent review of " $A$ ". guttata and its sister species " $A$ ". cinericia uncovered a number of important differences with other members of the genus Audre which might eventually result in their separation as a distinct genus. The genus Audre is currently under review as part of a forthcoming phylogenetic revision of the riodinid tribe Nymphidinii. (J. Hall, pers. comm.)

The collaboration between the two of us resulted in the present article in which a new subspecies is described and suggests the uniqueness of the largely unknown fauna inhabiting the vast inland area between the Brazilian States of Minas Gerais and Maranhão.

1) Avenida Suba 130-25, Casa 6, Bogotá, Colombia.

2) Departamento de Entomologia, Museu Nacional, Universidade Federal do Rio de Janeiro. Quinta da Boa Vista, São Cristóvão, Rio de Janeiro, Brazil. 


\section{MATERIALS AND METHODS}

During the course of the study the senior author examined collections in Argentina and Uruguay, namely the Instituto Miguel Lillo, Tucumán (IML) the Museo Argentino de Ciencias Naturales, Buenos Aires (MACN), the Museo de Ciencias Naturales (MLPA) at la Plata, and the Museo de Historia Natural de Montevideo (MHNM) and Centro de Estudios de Ciencias Naturales (CECN) in Montevideo. In Brazil, material at the Departamento de Zoologia da Universidade Federal de Pananá, Curitiba (DZUP) and the Museu Nacional, Rio de Janeiro (MNRJ) was examined by one of us (CJC), in addition to that of two private collections (CJC, Nirton Tangerini). The type of S. cinericia had been photographed earlier at the Museum fhr Naturkunde der Humbolt Universität, Berlin (MNHU). Eighteen specimens and 6 genitalia preparations were studied. Measurements were made with an ocular micrometer and calipers. References to wing cells and veins follow the Comstock-Needham system in MILLER (1969) and the genitalia terminology is from KLOTS (1970).

\section{"Audre" guttata guttata (Stichel, 1910)}

Figs 11-14

Hamearis guttata Stichel, 1910: 46. Holotype female, ARGENTINA: Mendoza (MNHU)[examined].

= Apodemia minuscula Giacomelli, 1911, Holotype male, ARGENTINA, La Rioja (MACN) [examined]. Synonymized by H. Stichel, 1931.

$=$ Hamearis notialis $f$. guarapensis Kohler, 1923, Holotype male, ARGENTINA, La Rioja (MACN) [examined]. Synonymized by H. Stichel, 1931.

Nomenclature. Hamearis guttata was described by Stichel based on a female specimen from the foothills of the Andes at Mendoza, Argentina. The lack of a description of the male resulted in two synonyms, $H$. miniscula, and $H$. guarapensis (Köhler, 1923) described as a form of Audre notialis. Both holotypes are from La Rioja, Argentina, north of Mendoza, have lectotype labels placed by G. Lamas and are located in the Museo Argentino de Ciencias Naturales, Buenos Aires (MACN).

Diagnosis. "Audre" guttata is a small species with average forewing length of $11 \mathrm{~mm}$, appearing at first glance as a small Audre with white spots much like Audre signata Stichel, 1910, but easily separated by the scalloped distal margin of the forewing. The ventral hindwing is diagnostic with lighter ground color at the base, a darker discal area and lighter limbal area. The females are generally lighter with larger spots than the males and an orange margin enclosing a row of marginal black spots between the veins.

Discussion. STICHEL (1910) described $H$. guttata with another similar species, H. cinericia Stichel, 1910 in the genus Hamearis Huebner. In the Genera Insectorum (1911), he placed both species in a special section, the Cinericiiformes. HEMMING (1934) transferred all the Neotropical species in Stichel's Hamearis, including $H$. cinericia and $H$. guttata, to the genus Audre Hemming.

Examination of specimens of " $A$ " guttata, however, suggests that this species is not closely related to A. epulus (Cramer, 1775), the type species of the genus Audre, and may eventually be described as a separate genus. "A." guttata 


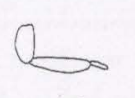

1
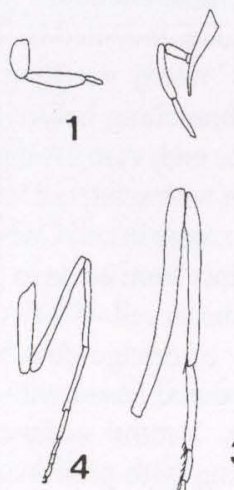
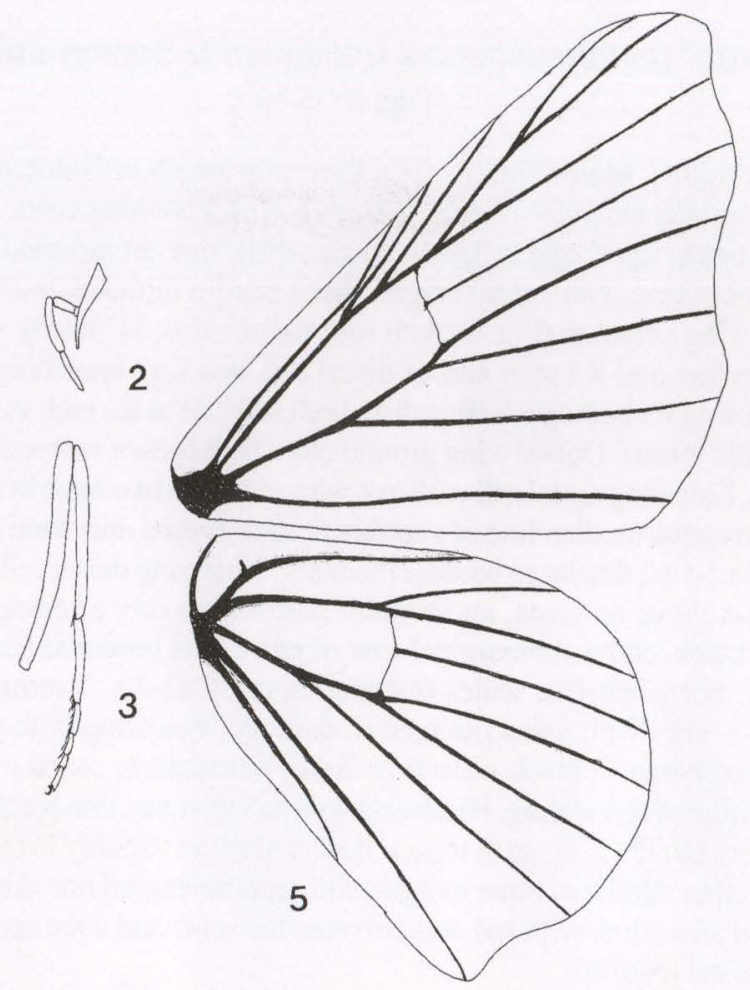

Figs 1-5. "Audre" guttata. (1) Palpi; (2) male foreleg; (3) male middle leg; (4) female foreleg; (5) wing venation.

lacks the inflated male probosis, a rami and rami support on the male genitalia, toothed tips on the valvae, bufurcated uncus and sexually dimorphic labial palpae, which are typical of the genus Audre. Unlike Audre the distal margins of both wings are scalloped instead of straight, resembling those of the genus Calydna. The signa in the female genitalia are located cephalad in "A." guttata and caudad in Audre. Finally, "A." guttata rests with wings outspread, while Audre species rest with them closed. Recent cladistic analysis on the Nymphidiini (PENZ \& DEVRIES 1999) support the separation of the Cinericiiformes from Audre.

Range and Habitat. The nominate subspecies inhabits western Argentina in the foothills of the Andes in Mendoza and Rioja Provinces north to Salta Province. It has not been recorded from Paraguay or the Chaco in Bolivia.

Biology. Little is known of the life history of this species. However, there is a specimen of " $A$." guttata from Loreto, Missiones, in the MLPA collection with a note on the label "con Crematogastor" (sic) referring to the ant genus Crematogaster, suggesting it may be mymecophilous.

R. Eisele.

Material Examined. ArgentinA: 4m 2f, 1 km E. Pichinal Salta, $300 \mathrm{~m}$. leg 


\section{"Audre" guttata jaibensis Callaghan \& Soares subsp. n.}

Figs $8,15-18$

Description. Male (Figs 15, 16). Forewing length of Holotype $12.9 \mathrm{~mm}$, and material examined between 12 and $14 \mathrm{~mm} .(\mathrm{n}=6)$. Forewing costa straight, slightly curved just before apex; apex slightly falcate, distal margin indented below apex and in middle; hindwing with costa straight, distal margin rounded, indented before anal angle. Forewing venation (Fig. 5) with four radial veins, SC nearly touching R1; R2 branching before and R3 after end of discal cell, and Cul branching before the cell. On the hindwing Rs branches before discal cell and $\mathrm{Cul}$ at the end; vein $3 \mathrm{~A}$ terminates halfway to the tornus. Dorsal wing ground color dark brown with scattered white and orange dots. Forewing discal cell with two white dots and two more in cell Cu2-1 A $+2 \mathrm{~A}$ below; an irregular median line of variable reddish-brown dots from costa to $1 \mathrm{~A}+2 \mathrm{~A}$, that in cell $\mathrm{Cu} 1-\mathrm{Cu} 2$ displaced basad; cilia black. Hindwing discal cell with two yellow dots and one above on costa, an irregular postmedian row of orange dots bordered basad with black, and a submarginal row of black dots bordered basad with orange, cilia brown. Long hair-like scales scattered in cell Cu2-2A. Ventral surface ground color green - gray with veins outlined in dark red. Forewing with prominent white dots bordered basad in black reflecting dorsal maculation; costal margin near apex with an infusion of red scaling. Hindwing with an indistinct, thin band of white scaling reaching from middle of costa to tornus, bordered basad variably in red, and branching below the cell to middle of inner margin, and a prominent red line at end of discal cell; submarginal area white with red dots between the veins and a red spot at tornus, a red line along distal margin.

Head, thorax, and abdomen dark brown dorsad, uniform white scaling ventrad; antennae brown, with white scales between sections, club weak; orbit white, frontoclypeus with long brown scales, white in center; labial palpi (Fig. 1) short, not protruding beyond front when viewed dorsally, first two segments with dense, white scales, third segment brown with white tips. Thorax pubscent dorsad, tegula orange- brown; forelegs (Fig. 2) white, with coxa thin and wedge-shaped, slightly curved, trochanter branching off slightly more than half way to the tip, with long scales, tarsus unimerous, middle (Fig. 3) and hind legs with a tibial spur and a group of three spines on distal tip of tarsal segments.

Genitalia (Fig. 6) with uncus undivided, broad, medially slightly pointed on posterior edge; anterior margin of tegumen (Fig. 7) indented; vinculum thin, slightly widened in middle, not attached to valvae; valvae fused dorsad, separating into two points at tip, pedicel broad, extending caudad to a sclerotized squared tip, then turning sharply towards base; aedeagus pointed.

Female (Figs 17, 18). Average forewing length $14.5 \mathrm{~mm}$. Dorsal surface ground color dark brown with prominent yellow maculation as on male. In addition, there is a submarginal row of dots bordered distad with black. Ventral surface forewing yellow- brown with white maculation reflecting dorsal surface and bordered basad with black; margin dark red. Hindwing yellow infused with red-brown scaling; dorsal maculation appears faintly, a thin white line crosses discal area from the costa to center of dorsum; termen red. 

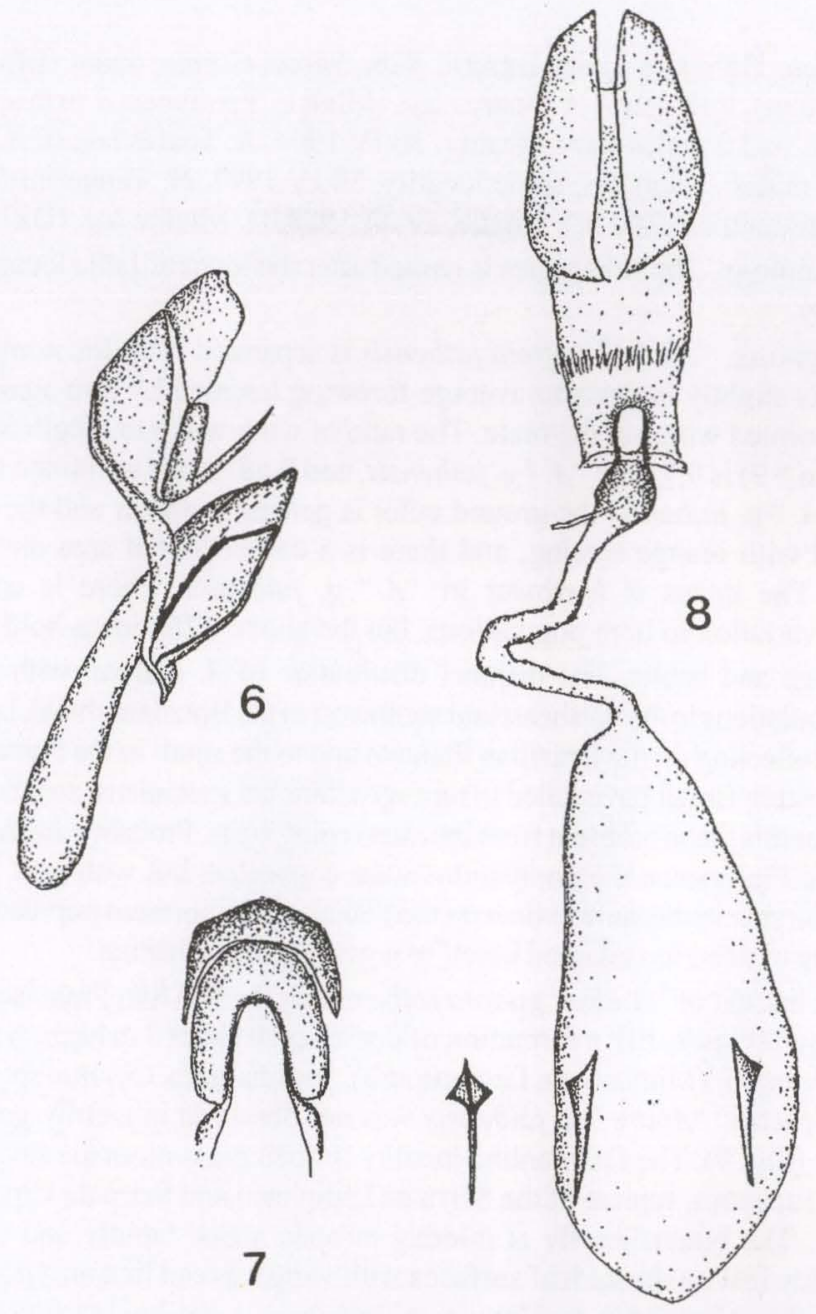

Figs 6-8. "Audre" guttata. (6) Male genitalia, lateral view; (7) anterior margin of male tegumen; (8) female genitalia.

Head, thorax and abdomen dark brown dorsad, white scaling ventrad; frons brown with white scaling, palpi as in male. Foreleg (Fig. 4) normal.

Genitalia (Fig. 8) with papillae anales blade-like, elongated, setose, dorsally and ventrally deeply bisected; ductus bursae short, wider in middle; ductus seminalis joins dorsally in middle of the base; ostium bursae with oval opening, corpus bursae located at the anterior end of abdomen, and is connected to the ductus bursae by a wide, unsclerotized tube; corpus bursae elongated with two pointed, sclerotized, invaginated signa located cephalad. Spermatophores observed in both females dissected had very long, wide tails, reaching from corpus bursae along tube to ductus bursae. 
Types. Holotype male. BrazIL \#26, Minas Gerais: Jaiba (Mocambinho, Carasco 490 m), 9.III.1997, A. Soares leg. (MNRJ). Paratypes: 3 males, same data as Holotype, and 2 males same locality, 30.IV.1994, A. Soares leg. (CJC) (MNRT, USNM); 2 males, 2 females, same locality, 30.IV.1997, N. Tangerini leg.; Minas Gerais: Diamantina (1300 m), 1 male, 28.XI.1988, O. Mielke leg. (DZUP).

Etymology. The subspecies is named after the town of Jaiba located near the type locality.

Diagnosis. "Audre" guttata jaibensis is separated from the nominate subspecies by its slightly larger size average forewing length $12.9 \mathrm{~mm}$ against $11 \mathrm{~mm}$ and more pointed wings in the male. The ratio of wing width to length of the males examined ( $\mathrm{n}=9$ ) is 0.71 for " $A$. " g. jaibensis, and 0.68 for the nominate subspecies. Also, on " $A$." g. jaibensis the ground color is generally darker and the white dots are infused with orange scaling, and there is a darker limbal area on the ventral hindwing. The uncus is narrower in "A." g. jaibensis. There is considerable individual variation in both populations, but the above differences hold generally.

Range and habits. The disjunct distribution of $A$. guttata, with completely isolated populations to the northeast and southwest of the Brazilian shield, is intriguing. Extensive collecting on the Brazilian Planalto and to the south in the Pantanal, Chaco and southeastern Brazil have failed to turn up additional specimens, so it can be safely assumed that this taxon is absent from the intervening areas. Probably during the colder times of the Pleistocene the populations were connected, but with post Pleistocene warming, the species became extinct on the Planalto. The northern population, instead of becoming extinct, has adapted itsself to a warmer, dryer habitat.

The habitat of "Audre" guttata jaibensis on the Rio São Francisco is known as "Caatinga" (Figs 9, 10), a formation of dense scrub about $3 \mathrm{~m}$ high, typical plants being "espinheiro"(Mimosa sp., Leguminosa), arranha-gato, Cassiae sp. and several species of cactus. "Audre" g. jaibensis was not observed in nearby gallery forest formations (Fig. 9). The Diamantina locality is open grass montane savana, known as campos rupestres, typical of the Serra de Espinhaço and Serra do Cipó, from 900 to $1500 \mathrm{~m}$. The butterflies fly at midday in open areas, rapidly and close to the ground. They rest on dorsal leaf surfaces with wings spread like an Apodemia. The flight period is November to May. A. g. jaibensis is not known outside the two localities; however, as the Caatinga habitat is found from northern Minas Gerais to Maranhão, it is probably more widespread.

\section{"Audre" cinericia (Stichel, 1910)}

Hamearis cinericia Stichel, H. 1910: 46. Holotype female, Argentina: [no further data] (MNHU) [examined]

= Hamearis precaria Schweitzer \& Kaye, 1941: Holtype female, Uruguay: Paysandu, Casa Blanca (MHNM)[not traced].

= Hamearis precaria ab. similis Schweitzer \& Kaye, 1941: Holotype female, UrUGUAY: Paysandu, Casa Blanca, (MHNH) [not traced].

Nomenclature. "Audre" cinericia was described by Stichel from a unique female specimen from "Argentina", deposited in the MNHU. The type is illustrated in figures 19 and 20. The lack of a male specimen led SCHWEITZER \& KAYE (1941) 

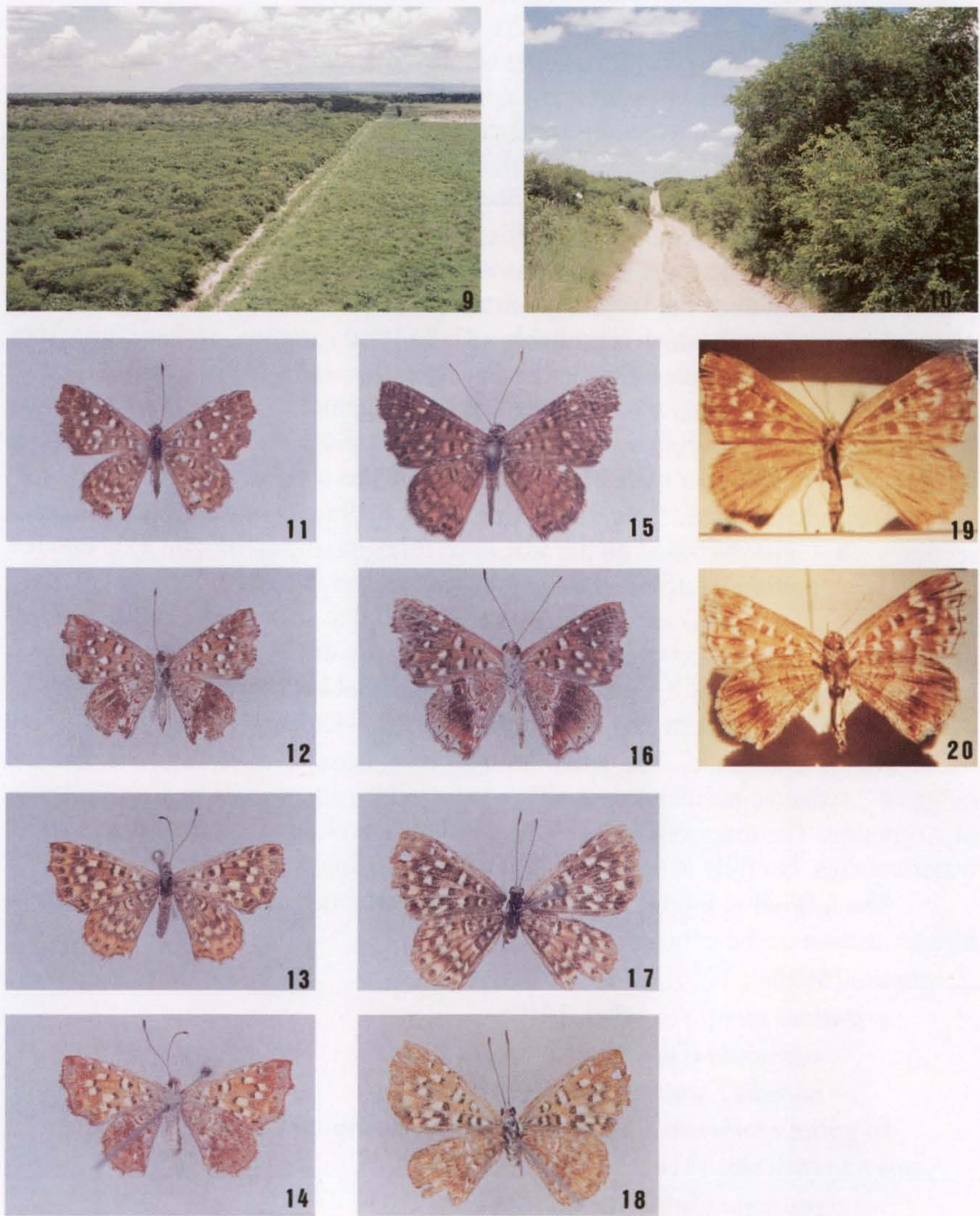

Figs 9-20. (9) Type locality of "Audre" g. jaibensis, near Jaiba, Minas Gerais (area on left is virgin caatinga brush with gallery forest behind); (10) close-up of caatinga vegetation at type locality: (11-14) "Audre" guttata: (11) male, dorsal surface; (12) male, ventral surface; (13) female, dorsal surface; (14) female, ventral surface; (15-18) "Audre" guttata jaibensis: (15) male holotype, dorsal surface; (16) male holotype, ventral surface; (17) female, dorsal surface; (18) female, ventral surface; (19-20) "Audre" cinericia, female holotype, MNHU: (19) dorsal surface; (20) ventral surface. 
to describe Hamearis precaria and a female aberration similis from Paysandu, (Casa Blanca) Uruguay, on the border with Argentina to the northwest of Montevideo. Despite a search of the collections at the MHNM and the CECN in Montevideo by CJC, the types of these two taxa, or any additional specimens were not located. The curators said that due to a leaking roof, much of the collection at the MHNM had been destroyed, which may have been the fate of the types. (Schweitzer and Kaye types located were Hamearis erycina affinis and Hamearis almironensis). However, comparison of Schweitzer and Kayes' illustrations and descriptions leave no doubt but that they are synonyms of $A$. cinericia Stichel. Form similis is identical to Stichel's type, whereas the female illustrated as H. precaria has a solid instead of broken forewing band, which is probably an individual variation, as they come from the same locality. The male described as that of H. precaria is in fact a typical Audre, probably Audre chiliensis ssp as confirmed by the genitalia illustration. The male has a straight distal margin on both wings and a typical Audre chiliensis ventral surface pattern. Thus, the male of $A$. cinericia remains a mystery.

Diagnosis. "Audre" cinericia was placed by Stichel in the Cinericiiformes section with $A$. guttata based on the scalloped forewing distal margin. That and the general wing pattern is sufficient to include it as a sister species to "Audre" guttata. The forewing dots are larger than A. guttata and tend to form a solid band, as in $A$. precaria. The ventral surface of the hindwing is quite different with the basal area brown with three lighter dots, a distinct lighter medial band bordered distad by an irregular figure at the apex and white spot in cell M3-Cu1.

Range and habits. The small amount of material known suggests that the range of "Audre" cinericia is central Uruguay and the adjacent Entre Rios province of Argentina. The topography is rolling grasslands broken by gallery forests along water courses. Nothing is known of the habits or biology of this species.

The following synonymic list summarizes the classification of the Cinericiiformes section of the genus Audre:

guttata (Stichel, 1910)

a) guttata guttata (Stichel, 1910)

= miniscula $($ Giacomelli, 1911)

= notialis $f$. guarapensis (Köhler, 1923)

b) guttata jaibensis Callaghan \& Soares, subsp. $\mathbf{n}$.

cinericia (Stichel, 1910)

$=$ precaria $($ Schweitzer $\&$ Kaye, 1941

$=$ precaria $a b$. similis $($ Schweitzer \& Kaye, 1941)

ACKNOWLEDGEMENTS. The authors wish to thank CODEVASF/SYNTEC 3 Engenharia e Controle de Corrosão Ltda. for the financial assistance which permitted the faunistic survey to be undertaken, and the reserve guard, Sr. Sabastião. Drs. Keith Brown Jr, Olaf Mielke and Jason Hall made many helpful comments on the draft. Finally, our thanks to Dr.Carlos S. Carbonell for providing CJC with access to the MHNM, and Dr. Ronderos (MALN), Dr. Abas (MACN), Dr. Mey (MNHU), and Dr. Olaf Mielke (DZUP) for access to the collections under their care. 


\section{REFERENCES}

Giacomelli, E. 1911. Lepidópteros riojanos nuevos o poco conocidos. An. Soc. Cient. Argent. 72 (1): $19-40$.

Hemming, F. 1934. Notes on three genera proposed by Jacob Hubner in the first volume of his Sammlung Exotische Schmetterlinge, with a definition of a new genus. Entomologist 67 (854): 156-157.

KLots, A. 1970. Lepidoptera, p. 115-129. In: S.L. TUXEN (Ed.). Taxonomist's Glossary of genitalia in insects. Munksgaard, Copenhagen.

KÖHLER, P. 1923. Fauna argentina. Lepidoptera e collectione Alberto Breyer. I. Teil. Rhopalocera. Systematischer Katalog und studien, Berichtigungen u. Neubeschreibungen. Z. fhr. wiss. Ins. 18 (12): $1-34$

MiLler, L.D. 1969. Nomenclature of wing veins and cells. Jour. Res. Lepidopt. 8 (2): 37-48.

Pentz, C.M. \& P.J. Devries. 1999. Preliminary Assessment of the Tribe Lemoniini (Lepidoptera: Riodinidae) based on adult morphology. Amer. Mus. Nov. (3284): 1-32.

Schweitzer, F. \& P.G.W. Kaye. 1941. Lepidópteros del Uruguay. An. Mus. Hist. Nat. Montevideo, $2^{a}$ serie, $5(2): 1-14$.

Soares, A.; C.E.A. Júlio; C.A. CaEtano; N. Tangerini; A.C. DE. Faria \& J.E. Da Costa. 1998. Lista da Lepidopterofauna diurna da região da Calha do Rio São Francisco, Estado de Minas Gerais, Municípios de Itacarambi, Jaiba, Manga e Matias Cardoso. Bol. Mus. Nac., n.s., Zool.., Rio de Janeiro, 402: 1-11.

StiCHEL, H. 1910. Vorarbeiten zu einer Revision der Riodinidae Grote (Erycinidae Swainson) Lep. Rhop. Berl. ent. Z. 55: 46

. 1911. Fam. Riodinidae, Subfam. Riodininae. In: P. WyTSMAn (Ed.). Genera Insect. 112B, p. $239-452$.

Recebido em 28.X.1999; aceito em 19.VII.2001. 